\title{
Examining the Emotional Semantic Orientation of Gifted Students Towards the Flipped Learning Model
}

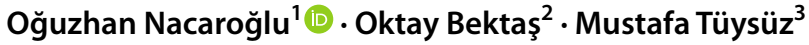

Accepted: 19 November 2021 / Published online: 29 November 2021

(c) The Author(s), under exclusive licence to Springer Nature B.V. 2021

\begin{abstract}
The aim of this study was to examine the emotional semantic orientation of gifted students towards the flipped learning model (FLM). An explanatory sequential design, one of the mixed research methods, was utilized in this research. Participants were 53 gifted students, who continued their education in a Science and Art Center in the Eastern Anatolia Region, in the first semester of the 2019-2020 academic year. Participants stated the FLM to be fun, different, instructive, useful, advantageous, and flexible in terms of in-class practices. They also found the FLM to be fun owing to its features such as facilitating learning, being flexible, and providing opportunities for practice. Moreover, the participants regarded the FLM as fun, useful, advantageous, flexible, and effective in terms of out-of-class practices. Another result was that no significant difference was found between the emotional semantic orientations of the female and male gifted students in terms of in-class practices. However, in terms of out-of-class practices, there was a significant difference between the scores obtained from the answers given for the effective-ineffective adjective pair in favor of male participants, while there a significant difference between the scores obtained from the answers given for the fun-boring adjective pair in favor of female participants. Investigation of integrating hybrid learning approaches such as the FLM and evaluating students' cognitive and affective developments in other disciplines and subjects should be conducted to obtain more data on this approach.
\end{abstract}

Keywords Emotional semantic orientation · Exploratory sequential design · Flipped learning model $\cdot$ Gifted students

Oğuzhan Nacaroğlu

onacaroglu44@gmail.com

Oktay Bektaş

obektas@erciyes.edu.tr

Mustafa Tüysüz

mustafatuysuz@yyu.edu.tr

1 Malatya Science and Art Center, Malatya, Turkey

2 Faculty of Education, Erciyes University, Kayseri, Turkey

3 Faculty of Education, Van Yuzuncu Yil University, Van, Turkey 


\section{Introduction}

Today, the internet and computers have become important parts of our lives especially as a result of developments in technology. The opportunities that technology has offered have also caused changes in individuals' socialization, communication, creative thinking, learning preferences, and skills (Helsper \& Eynon, 2010). These changes have affected education as well as other fields and found a place at all levels of education, from kindergarten to university, and in such a way that it includes the lifelong learning process (Hubers et al., 2020; Robin, 2008). Unlike other periods, learning tendencies and preferences of today's students have differed along with these changes, and these students are now referred to as "digital natives" (Prensky, 2001). Additionally, to emphasize the impact of the new changes brought by the twenty-first century on the new generation, these students are called "N-generation", "Z-generation", and "alpha generation" besides "digital natives" (Pedró, 2006). New approaches should be introduced to meet the needs of today's students in educational environments (Naylor \& Keogh, 1999). The Flipped Learning Model (FLM), which is among the rotation models of blended learning, has begun to be used in learning environments (Bishop \& Verleger, 2013). Although this is a new model that has emerged with the rapid development of technology, its use in learning environments is ever increasing (Strelan et al., 2020).

The FLM is often referred to as "flipped learning" and "flipped classroom" in the literature (Bates et al., 2017). In its simplest definition, the FLM is the rotation of studies performed outside the classroom with knowledge-based theoretical teaching within the classroom (Bergmann \& Sams, 2012). In this model, in which the responsibility for learning is given to students, the process of knowledge transfer in the class is carried out of the classroom through various online tools (Hamdan et al., 2013). Students learn the content that is sent to them in accordance with their learning pace without a certain time limit and they come to the classroom ready for learning (Strelan et al., 2020). In classroom practices, more time is spent on high-level learning activities under the guidance of the teacher (Abeysekera \& Dawson, 2015; Cheng et al., 2019). Therefore, the FLM has four components -flexible learning environment, learning culture, purposeful content, and professional educator and the model should be organized within the framework of these components (Flipped Learning Network, [FLN], 2014). The components of the FLM are summarized in Fig. 1 (FLN, 2014).

As shown in Fig. 1, while courses suitable for the FLM are processed within the flexible learning environment component, learning environments should be organized so that students can do individual and group work. For this purpose, it is important to use active learning strategies. In addition, learning environments should be created in such a way as to allow students to learn at any time and place in accordance with the individual speed of students. (Wanner \& Palmer, 2015). In this way, students can be offered rich learning opportunities. As part of the learning culture, students should be offered a rich opportunity to learn, especially during the course, and studies that center the student should be planned. Here, the needs of the student must be observed. In addition, students who take responsibility for learning in out-of-class practices should be offered opportunities to evaluate their own learning. At the point of evaluating students' learning, it is important for teachers to guide students. Accordingly, it is recommended that teachers organize in-class and out-ofclass practices in accordance with the learning styles of students (EduTrends, 2016). As part of the professional educator component, the teacher should give instant feedback to students, especially in extracurricular applications, and guide students by observing and 


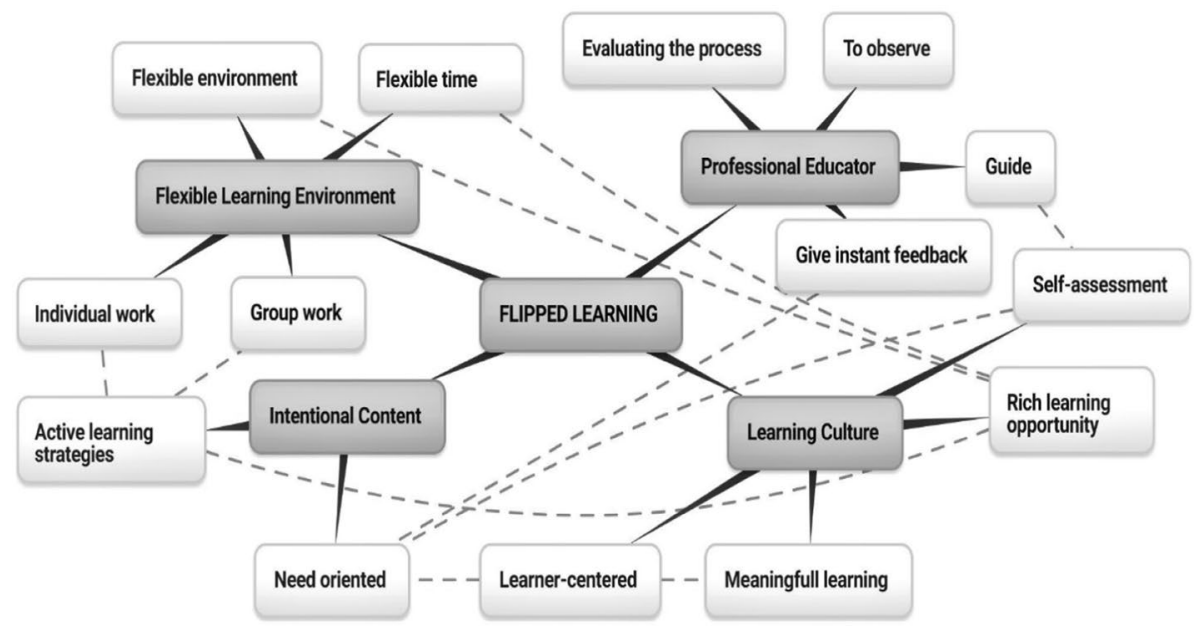

Fig. 1 Components of the FLM

evaluating the process in and out-of-class. During out-of-class times, the teacher must prepare the content that students will deliver to the students in a way that is appropriate for the student and ensures the interaction of the teacher-student and the student-student. As a matter of fact, in the FLM, it is recommended that the content that will be delivered to students during out-of-class times be prepared to meet the student's requirements and delivered through interactive learning systems that allow instantaneous conversion (EduTrends, 2016). Therefore, learning technologies appropriate to students and conditions should be used in the FLM (Strayer, 2011).

The improvement of educational technologies can be shown as a crucial factor in the spread of FLM (Belovitskay et al., 2021). Educational technologies are used by students in the process of learning subjects at home and in realizing activities in the classroom (Halili et al., 2021). Thanks to educational technologies which are in the form of online course content, videos suitable for the school subject, and teaching systems, it is ensured that students access the content of the subject and become prepared before they come to the class (Fulton, 2012). Moreover, electronic books, audio recordings, class notes, and presentations can also be used within the scope of out-of-class practices (Wei et al., 2020). These technology-supported out-of-class practices offer students an opportunity to learn about the subject of the lesson before they come to the class, to spend more time for classroom activities (Pierce \& Fox, 2012), and to do different activities to grasp the knowledge they obtain (Davies et al., 2013). All these descriptions show the difference between the FLM and traditional classroom models (Lundin et al., 2018).

Students are made to acquire gains in the remembering, understanding and application steps of Bloom's taxonomy through in-class practices in traditional classroom models. However, high-level learning activities are expected to be performed by students at home on their own and without the help of their teachers. In the FLM, however, activities related to the remembering, understanding and application steps are carried out in out-ofclass time and high-level activities are carried out during learning in the classroom. Hence, a significant part of in-class time in the FLM is allocated to higher level activities under the guidance of the teacher (Kissi et al., 2018). These explanations show that the FLM has many advantages (Lundin et al., 2018; Moffett, 2015; Wei et al., 2020). The FLM not only 
provides students with a flexible learning environment, but it also gives students an opportunity to learn subjects at an appropriate time and place (Moffett, 2015). This advantage, which emphasizes the flexible learning environment of the FLM, contributes to increasing students' capacity to control their own learning and to develop their self-regulated learning skills (Gerstein, 2012). The FLM, which contributes to creating a culture of learning in the classroom, helps students to internalize the knowledge they have learned by encouraging them to do individual or group work and to evaluate the knowledge obtained from different perspectives through problem solving and project studies (Missildine et al., 2013). However, as every learning model may have, the FLM also has disadvantages. In this context, McCarthy (2016) has noted that students can show resistance to this new model and come to the classroom unprepared. Moreover, Kim et al. (2014) have reported that when students are not given the necessary support while conducting lessons in accordance with the model, students can experience lack of motivation and feelings such as anxiety. Furthermore, the disadvantages of the FLM include teachers' lack of competence in the model (Peled, et al., 2015), students' low self-regulated learning skills (Talbert, 2014), and the unsuitability of some school subjects for the model (Kuo et al., 2012). Despite these disadvantages, the number of studies examining the suitability of the FLM for different courses and cultures has increased especially since 2012 (Bishop \& Verlager, 2013).

\section{Review Literature}

When the literature is examined, there are investigations of the effectiveness of the FLM in software, mathematics, physics, chemistry, health care, statistics, engineering and many other fields (Behmanesh et al., 2020; DeSantis et al., 2015; Fernández-Martíne et al., 2020; Ghanaat \& Habibzadeh, 2021; Gannod et al., 2008; Huang et al., 2020; Jdaitawi, 2020; Kettle, 2013; Kong, 2015; Lestari, 2021; Mason et al., 2013; McLaughlin et al., 2014; Pierce \& Fox, 2012; Talbert, 2014; Touchton, 2015; Webb \& Doman, 2020; Yestrebsky, 2015). Moreover, it is seen that studies examining the effects of the FLM on many variables such as academic achievement (Hwang et al., 2021; Pierce \& Fox, 2012), attitude (Chao et al., 2015; Güç, 2017; Sağlam, 2016; Webb \& Doman, 2020), motivation (Çukurcubaşı, 2016; Halili et al., 2021), mental risk taking (Çakır \& Yaman, 2018), and reading level (Cashin, 2016) are increasing in the literature. The literature review indicates that the use of the flipped learning model (FLM) in learning environments has increased in recent years. (Birgili et al., 2021). Al Mamun et al. (2021) stated that the importance of FLM increased even more during the pandemic. In this context, Thai et al. (2017) emphasized that FLM is a promising way to increase students' performance. Similarly, Hwang et al. (2021) revealed that the flipped learning model improves students' learning performance by enhancing their higher-order thinking skills. On the other hand, Halili et al. (2021) concluded that FLM enhanced students' motivation to learn, and they had a positive perception towards FLM. They also suggested conducting research involving different ages and groups to gain in-depth information on the application of FLM. Although the use of FLM has increased in recent years, more studies are needed, especially on learner attitudes (Jdaitawi, 2020).

Attitude, an important concept of social psychology, is defined as the tendency to react to an event, situation, or person positively or negatively (Ajzen \& Fishbein, 1988). The literature emphasizes that attitude resistant to change is a tendency to prepare the behavior rather than performing the behavior itself. Attitudes direct human behavior and contain cognitive, emotional, and behavioral elements. The literature includes a number of studies 
that have examined the effect of the FLM on students' attitudes (Ceylaner, 2016; Chao et al., 2015; Güç, 2017). Al-Harbi and Alshumaimeri (2016), who examined secondary school students' attitudes towards FLM, conducted semi-structured interviews with students. According to the interviews' findings, the students stated that their attitudes towards FLM were generally positive. Moreover, some students mentioned that their workload increased in extracurricular practices. Güç (2017) examined the effect of the FLM on students' attitudes toward mathematics lessons and concluded that the model did not create a statistically significant difference in the attitudes of the groups. Leatherman and Cleveland (2020) reported that a significant portion of the students had negative attitudes towards FLM. However, Ceylaner (2016) reported that the FLM positively contributed to the attitudes of high school students toward English lessons. Fard et al. (2021), who investigated undergraduate students' attitudes towards FLM, reported that most students developed positive attitudes towards FLM and facilitated their learning. Examining the effect of FLM on students' learning attitudes, Chao et al. (2015) stated that the learning attitudes of the experimental group students increased positively at the end of the application. Su and Chen (2018), who investigated the effect of FLM supported by instant question generation and feedback technologies on students' learning attitudes, stated that FLM positively affected students' learning attitudes. Examining students' attitudes towards FLM, Singay (2020) concluded that FLM provides an appropriate learning environment and allows collaboration and the use of technology. Chung and Lee (2018), who reported that FLM was influential on undergraduate students' learning attitudes, suggested that more research should be conducted on the application of FLM. In support of this suggestion, Jiang et al. (2021), as a result of their study, revealed the importance of determining how readiness for different FLM practices may be related to students' attitudes.

\section{Summary of the Literature and Aim of Study}

Although there are many studies in the literature examining students' attitudes towards FLM, there is no consistency between the findings of these studies (e.g., Bell, 2015; Leatherman \& Cleveland, 2020; Tutal \& Yazar, 2021). In this regard, it is necessary to support the literature by conducting more investigations (Halili, et al., 2021; Jdaitawi, 2020). Lestari (2021) stated that it is crucial to determine students' attitudes towards FLM. Betaubun (2021) mentioned that identifying students' attitude towards FLM, whose utilize has enhanced especially during the COVID-19 process, should provide a different framework for the effectiveness of the model. On the other hand, Bin-Hady and Hazaea (2021) found that there is a positive relationship between students' attitudes towards FLM and their academic achievement. No study has also been found in the literature examining the emotional semantic orientations of gifted students towards FLM. It is thought that the positive or negative emotional meanings that students attribute to this model will be a determining factor in the effective use of the flipped learning model in learning environments (Ekici et al., 2015). As a matter of fact, semantic analyzes give an idea about the performance of individuals (Lake \& Murphy, 2021). The attitude of individuals towards a subject is hidden in the choice of words, and the words people use reflect what they think and how they feel. (Krauss \& Chiu, 1998). Thus, one way of examining individuals' attitudes towards an event or situation is to analyze the types of words they prefer and the linguistic emotion inherent in these words (MillerLewis et al., 2021). Moreover, experimental interventions can reveal a significant effect 
on the values of individuals' words. In this context, in the present study, it was tried to determine the emotional semantic orientations of the students regarding FLM, considering the scale of Osgood et al. (1957), one of the pioneers of the theory of computational meaning. Osgood et al.'s (1957) scale consisting of evaluation, power and activity dimensions has an orthogonal structure. The emotional semantic orientations of individuals can be revealed with this orthogonal structure. Emotional semantic orientation refers to the semantic value of individuals' attitudes toward an event or situation, in other words, what an individual's attitude means (Ekici et al., 2015). Therefore, in the present study, the attitudes of gifted students toward the FLM were examined emotionally as a single dimension and the emotional semantic orientations of gifted students toward the FLM were investigated within this context. The reason for this is that examining students' attitudes, which have different aspects and are affected by many internal and external factors, in terms of a single aspect or dimension is considered important. This study aimed to determine the emotional semantic orientation of gifted students toward the FLM, and the findings obtained can serve as a resource for researchers who want to work on this model, teachers who want to use the FLM in their lessons, and experts working in this field. Another aspect that distinguishes the current study from other investigations is that the sample of the study consisted of gifted students.

Gifted students, who have superior capacity in one or more skills compared to their peers, constitute the most important human resource of societies (Ataman, 2009). Although gifted students bear similarities with their peers in many respects, they should be considered as a different group in terms of intelligence, learning, and personality traits (Thomson, 2010). These students have high creativity, memory skills, imagination, and motivation; they can convey their knowledge to changing situations and prefer challenging tasks (Cavilla, 2019). As gifted students have many different characteristics compared to their peers and are important human resources for societies, it is not appropriate to use a single learning model in their education. When suitable learning facilities are not created, gifted students may encounter many problems (Preckel et al., 2010). Therefore, considerable importance should be given to education of these students and enriched learning models different those of from their peers should be used in their education (Subotnik et al., 2011). Literature review shows that many educational models have been used since these students were recognized. These models include many educational approaches such as the Purdue Model, Betts, and Kercher's Autonomous Learner Model (ALM), Renzulli's Enrichment Triad Model (ETM), the Grid Model, Guilford's Structure of Intellect Theory, Sternbergs' Triarchic Model, the William and Mary Integrated Curriculum Model (ICM), Tomlinson's Parallel Curriculum Model (PCM), the Talents Unlimited Model (TUM), and the Matrix Model. The FLM, rather than these models, was used in the science education of gifted students in the present study. The FLM model was selected for the education of these students because it includes out-of-class practices and thus contributes to the development of their lifelong and self-regulated learning skills, allows students to learn without time, resource and environment constraints with its flexible learning environment, and is suitable for planning and implementing appropriate high-level activities in accordance with the gifts of these students in the classroom. The main aim of the current study was to determine the emotional semantic orientations of gifted students toward the FLM as a result of in-class and out-of-class practices carried out in this model. In addition, emotional semantic orientation of gifted students toward the FLM was examined in terms of gender.

The interests and attitudes of female and male towards learning processes may be different (Gallagher \& De Lisi, 1994; Salami, 2021). However, gender is cited as one of the important variables that affect students' perceptions and attitudes in different 
learning environments (Huang et al., 2010; Wehrwein et al., 2007). In this context, gender, a demographic category, which is determined based on the biological characteristics of individuals, is a common variable in the research problems of studies conducted in social sciences. In the literature, there are a limited number of studies examining the attitudes of individuals from different sectors toward the FLM in terms of gender. For example, Broderick (2016) examined the attitudes of faculty members toward the FLM and found that the participants' attitudes did not differ in terms of gender. Therefore, it is thought that examining the emotional semantic orientations of gifted students towards FLM in terms of gender might also contribute to the literature (Sağlam \& Arslan, 2018). The study differs from previous studies that have examined the effect of the FLM on attitude as its sample consisted of gifted students, used science lessons as the course, and included emotional semantic orientation toward the model as a variable. Based on the abovementioned explanations, answers to the following questions were sought:

- What are the emotional semantic orientation levels of gifted students towards the FLM?

- What are the views of gifted students about the FLM?

- Do the emotional semantic orientation scores of gifted students towards the FLM show a significant difference in terms of gender?

\section{Method}

\subsection{Research Design}

This study was prepared as an explanatory sequential design, which is a mixed research method. There are many different designs in the mixed method, which is based on collecting and analyzing quantitative and qualitative data together (Creswell, 2014). While qualitative or quantitative methods may be dominant in mixed research methods, studies with equal status are also carried out (Johnson et al., 2007). An explanatory sequential design is a research design in which qualitative data are collected first, then quantitative data are collected to explain the qualitative results in more detail (Ivankova et al., 2006). In this context, survey and holistic single-case research designs were used for the quantitative and qualitative dimensions of the study, respectively. A survey research design is a quantitative research design that is used in studies on relatively larger samples and in cases where an attempt is made to identify participants' characteristics such as skills, opinions, interests and perceptions about a subject or event (Fraenkel \& Wallen, 2006). This study used a survey research design to determine the emotional semantic orientation of gifted students toward the FLM. The holistic single-case research design used in the qualitative dimension of the research shows the results obtained for a specific case under investigation (Storey, 2007). As the study aimed to investigate gifted students' views about the FLM at the end of the ten-week implementation, a holistic single-case research design was used in the present study. 


\subsection{Research Group}

The study group from whom the quantitative data of the research were collected consisted of 53 gifted students who continued their education in the Recognition of Personal Talent program (BYF) in a Science and Art Center in the Eastern Anatolia Region of Turkey in the 2019-2020 academic year. The criterion sampling method, which is a purposeful sampling method, was used for determining the sample of the study. In this context, gifted students who took their lessons according to the FLM were included in the study group. Table 1 presents the socio-demographic characteristics of participating students.

When Table 1 is examined, 30 of the participants are female (43.4\%) and 23 are male (56.6\%) students. Among the students, 17 were 4th graders, 22 were 5th graders and 14 were 6th graders; their ages ranged from 9 to 11 years. Participants in the study group from whom the qualitative data of the study were collected were selected using the maximum variation sampling method, a purposeful sampling technique. In the maximum variation method, participants are determined in such a way that they are variable, analogous, and have similar or different backgrounds (Grix, 2010; Neuman, 2014). Accordingly, 12 gifted students in the quantitative study group who were determined to provide maximum variation in terms of gender and class level were included in the study group from whom the qualitative data were collected.

\section{Data Collections Tools}

\subsection{Emotional Semantic Orientations Scale}

Emotional semantic orientation of gifted students toward the FLM was determined using the semantic differential scale which was developed by Osgood et al. (1957). This scale is reported to be effective for understanding affective characteristics (Ekici et al., 2015). The scale consists of two parts: demographic information and scale items. The participants were asked to mark the status of their gender in the demographic information section of the scale to collect data regarding the third sub-problem of the study. The scale contains 10 adjective pairs, namely effective-ineffective, fun-boring, simple-complex, not tiringtiring, different-ordinary, easy-difficult, instructive-not instructive, beneficial-detrimental, flexible-rigid, and advantageous-disadvantageous. The relevant literature (e.g., Chao et al., 2015; Gerstein, 2012; Güç, 2017; Kim et al., 2014; Kuo et al., 2012; McCarthy, 2016; Strayer, 2011) was reviewed and the opinions of an expert in the field was obtained while determining the adjective pairs. Based on the expert's opinion, it was decided to use a 5-point Likert-type scale in this study. While calculating the values in general, those with

Table 1 Demographic information for the participants

\begin{tabular}{llll}
\hline Variables & Demographic features & $f$ & $\%$ \\
\hline Gender & Female & 30 & 43.4 \\
& Male & 23 & 56.6 \\
Grade level & 4th grade & 17 & 32.1 \\
& 5th grade & 21 & 39.6 \\
& 6th grade & 15 & 28.3 \\
\hline
\end{tabular}


a mean of 3.5 and above were considered as positive attitude, those between 3.5 and 2.5 as neutral, and those below 2.5 as negative (Lohr \& Bummer, 1992). Responses for adjectives were "always", "usually", "partially", "usually", and "always", starting from the positive one. Negative adjectives were reverse scored. Sample items of the scale are given below (Fig. 2).

Before the students responded to the items in the scale, they were informed about how to complete the scale form by explaining it through a sample demonstration. The students were allowed to fill the scale form by taking into account both in-class and out-of-class practices.

\subsection{Open-ended Questions}

Qualitative data were collected using a document consisting of open-ended questions. The form consisted of six questions. While preparing the form, the relevant literature (e.g. Chao et al., 2015; McCarthy, 2016; Strayer, 2011) was reviewed and questions aiming to reveal the emotional semantic orientation of gifted students toward the FLM were included in the form. In addition, two domain experts were consulted. The questions were arranged in such a way that students could express their opinions in terms of out-of-class and in-class practices. For example, the question "Do you think the flipped learning model is effective in learning?" was asked together with the question "Explain the reasons in terms of in-class and out-of-class practices."

\subsection{Data Collection Process}

To determine the emotional semantic orientation of gifted students toward the FLM, 10-week courses suitable for the FLM were taught within the scope of the science course. First, a meeting was held with the participating students and their parents, and they were informed about the FLM and research process. They were told that the lessons would be taught through in-class and out-of-class practices, that videos and worksheets for the subject for each week would be delivered to the students via online tools (Edpuzzle and

FLM in terms of in-class practices;

\begin{tabular}{|c|c|c|c|c|c|c|}
\hline & Always & Usually & Partially & Usually & Always & \\
\hline effective & & & & & & ineffective \\
\hline fun & & & & & & boring \\
\hline
\end{tabular}

FLM| in terms out-of-class practices;

\begin{tabular}{|c|c|c|c|c|c|c|}
\hline & Always & Usually & Partially & Usually & Always & \\
\hline effective & & & & & & ineffective \\
\hline fun & & & & & & boring \\
\hline
\end{tabular}

Fig. 2 Sample items of the scale 
Table 2 Topics covered according to the FLM

\begin{tabular}{llll}
\hline Weeks & Topics & Weeks & Topics \\
\hline 1st week & Elements and the Periodic system & 6th week & The pH concept and indicators \\
2nd week & Classification of elements and usage areas & 7th week & Ecological and carbon footprint \\
3rd week & Physical and chemical changes & 8th week & Global warming and climate change \\
4th week & Chemical reactions & 9th week & Cell division \\
5th week & Acids and bases & 10th week & Systems in the human body \\
\hline
\end{tabular}

Fig. 3 Bioplastic production (3rd week)

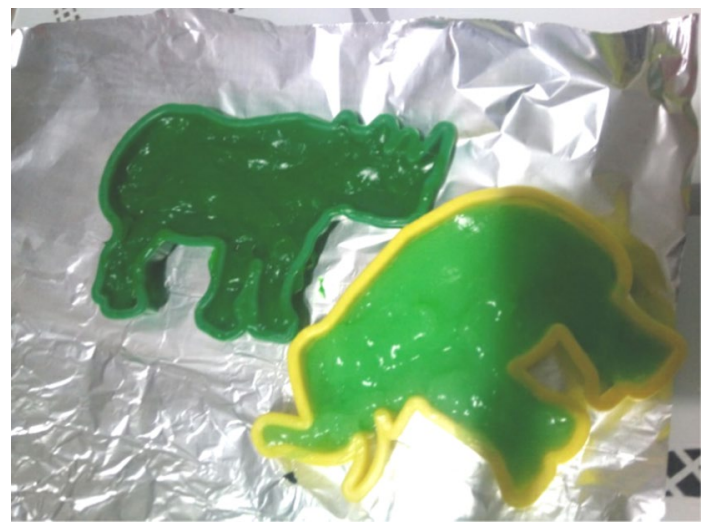

WhatsApp) at least one week before the lesson time, and that individual or group studies as well as experiments would be carried out during the lessons. Courses suitable for the FLM began to be taught the following week. Table 2 presents the subjects covered within the scope of the FLM.

Videos and worksheets available in educational platforms such as Khan Academy and EBA and prepared by researchers who are experts in each subject were delivered to the students via online tools. For FLM applications, many platforms such as Edmodo, groups (e.g., WhatsApp, Facebook), Khan Academy, Kahoot, Padlet, Google Classroom edpuzzle can be used to deliver content out the class to students (Onah et al., 2021). In the current study, Khan Academy and EBA education platforms, available to students in Turkey and containing content suitable for FLM, were chosen. Until the lesson time at the school, the students watched the lesson videos, completed their worksheets, and instantly communicated with the teacher of the lesson whenever they had difficulties. Parents of the students provided them with great support during the out-of-class practices in accessing the contents of lessons, performing the assigned tasks in the way they were requested and on time, and communicating instantly with the teacher of the lesson. Individual and group work activities were performed according to the relevant subject during the lessons. For example, the video and worksheets prepared for acids and bases were delivered to the students one week before the lesson. The video covered the definition of an acid, general properties of acids, acid samples in daily life, the definition of a base, general properties of bases, base samples in daily life, definition of a reagent and the effect of litmus paper on acids and bases. After the students had completed the necessary tasks on the subject, the in-class 
Fig. 4 Electrolysis experiment (4th week)

Fig. 5 Natural reagent experiment (6th week)

Fig. 6 Closed ecosystem (8th week)
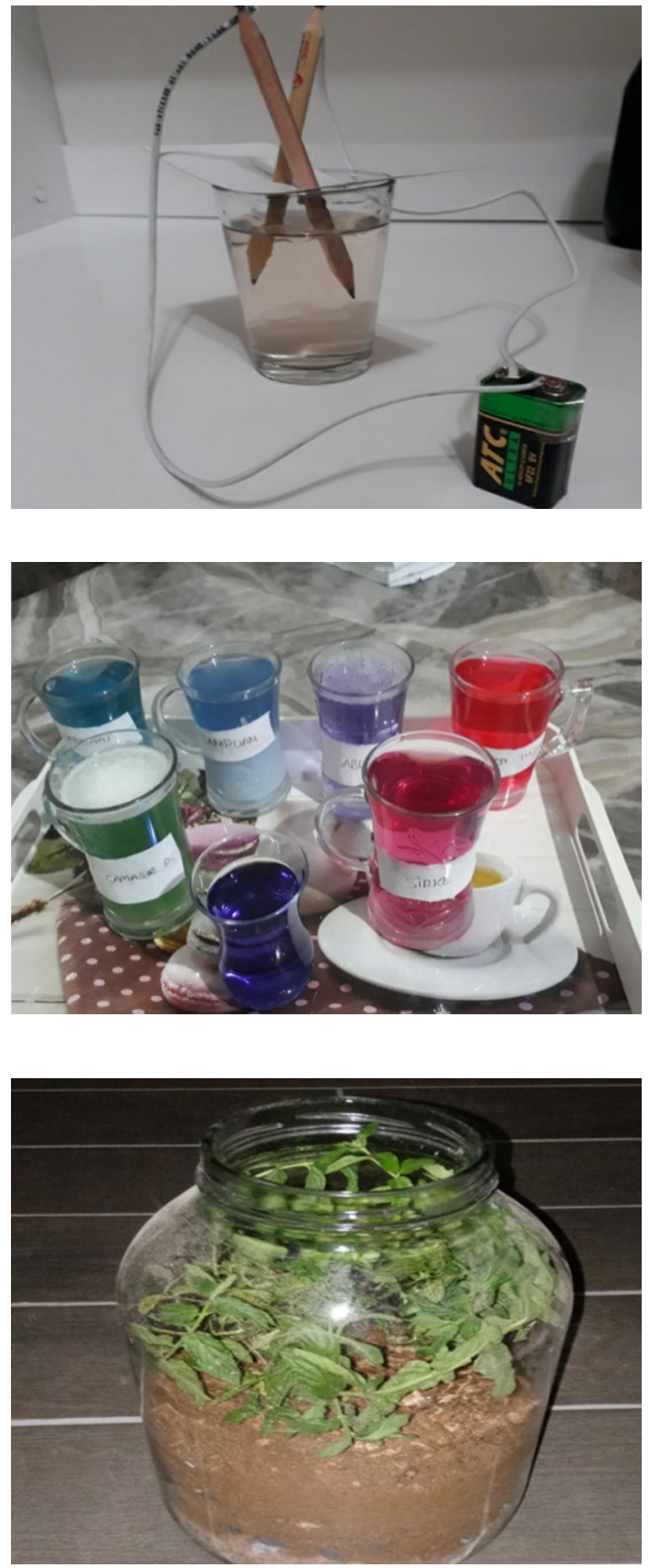

studies were begun. In this context, substances used in daily life as acids and bases were determined with the help of litmus paper. Then, the aqueous solutions of the substances were prepared, and the electrical conductivity of the acids and bases was checked. Students played mind games called rebus puzzles (picture-alphabet puzzles) about the concepts they 
had learned. A natural reagent was made from red cabbage juice and acidity and base statuses of the substances were examined (Fig. 5). In-class and out-of-class practices lasted for ten weeks. Some of the activities during the practices are shown (Figs. 3, 4, 5, 6):

\subsection{Data Analysis}

Descriptive and inferential statistical analysis was performed in the analysis of quantitative data. In this context, it was first checked whether the scores obtained in terms of gender were normally distributed. The normality test results in terms of gender are given in Table 3.

When the number of people in each group is less than 35, the Shapiro-Wilk test is recommended as the best choice (McKillup, 2012). Based on the Shapiro-Wilk test scores in Table 3, the scores obtained by the female and male participants in the in-class and out-ofclass practices dimensions of the scale showed a normal distribution $(p>0.05)$. However, the scores that the female participants obtained from the overall scale were not normally distributed. The mode, median and mean values of the scores of the female participants were close to each other and the kurtosis and skewness values were between $-1+1$; therefore, the scores were considered to show a normal distribution. (George \& Mallery, 2001). Parametric tests were used in the analyses of the data as the scores showed a normal distribution. Accordingly, an independent samples t-test was conducted to check whether there was a significant difference between the scores of male and female participants.

Qualitative data were analyzed using the inductive content analysis. First, the answers given to the questions in the form were confirmed by the participants. Then, codes and categories for the collected data were created (Corbin \& Strauss, 2007). While creating codes and categories, the authors first independently analyzed student responses. In line with the answers given, each author created their codes and categories. In line with the answers given, each author created their codes and categories. The meetings were then held to determine the authors' consensus and divergence. These meetings continued until full consensus was reached. Each code and category determined in this process was compared with student answers. Seven categories were created by considering the expressions in the emotional semantic orientation differential scale of Osgood et al. (1957). These categories are the effective, ineffective, fun, boring, advantageous, disadvantageous, and different/flexible. The codes and categories are examined in detail in the Results section. Pseudonyms (P1, P2 ... P12) were used for the participants expressing their opinions.

Certain strategies are used to ensure validity and reliability of qualitative studies. These strategies are credibility (internal validity), transferability (external validity), consistency

Table 3 Results of Normality Test

\begin{tabular}{|c|c|c|c|c|c|c|c|}
\hline & \multirow[t]{2}{*}{ Gender } & \multicolumn{3}{|c|}{ Kolmogorov-Smirnov } & \multicolumn{3}{|c|}{ Shapiro-Wilk } \\
\hline & & Statistics & $\mathrm{SD}$ & $p$ & Statistics & SD & $p$ \\
\hline \multirow[t]{2}{*}{ In-class } & Male & .126 & 23 & $.200^{*}$ & .970 & 23 & .690 \\
\hline & Female & .183 & 30 & .011 & .947 & 30 & .140 \\
\hline \multirow[t]{2}{*}{ Out-of-class } & Male & .104 & 23 & $.200^{*}$ & .986 & 23 & .981 \\
\hline & Female & .118 & 30 & $.200 *$ & .968 & 30 & .484 \\
\hline \multirow[t]{2}{*}{ Total } & Male & .128 & 23 & $.200 *$ & .948 & 23 & .267 \\
\hline & Female & .207 & 30 & .002 & .896 & 30 & .007 \\
\hline
\end{tabular}


(reliability), and verifiability (Merriam, 2009; Shenton, 2004). For credibility, the form developed was finalized after it had been submitted to a domain expert. In addition, the opinions of the participants were given as direct quotes in the Results section. Transferability strategies are used to ensure external validity in qualitative studies (Lincoln \& Guba, 2013). In this context, a purposeful sampling method was used in the current study. Information for the participants and each stage of the study were explained in detail. For consistency regarding the reliability and repeatability of the study, the data were analyzed separately by the researchers and then these results were evaluated together (Merriam, 2009). Also, common opinions of the researchers were taken into account in all the procedures carried out during the research process. For the verifiability strategy emphasizing the objectivity of the research, the developed form was administered to the participants who were determined to provide maximum diversity in terms of gender and grade level.

\section{Results}

\subsection{Emotional Semantic Orientations of Gifted Students toward the FLM}

Descriptive values of each adjective pair in the scale were calculated to determine the emotional semantic orientation of the gifted students toward the FLM. In this context, the mean scores, standard deviation values, percentages, and frequency values of the adjectives in the in-class and out-of-class dimensions of the scale are provided in Table 4.

In Table 4, students' opinions about the FLM in terms of in-class practices were as follows: always effective $(M=4.28 ; 43.4 \%)$, usually fun $(M=3.70 ; 49.0 \%)$, partially simple $(M=3.57 ; 49.1 \%)$, partially not tiring $(M=3.72 ; 45.3 \%)$, always different $(M=4.32$; $54.8 \%)$, partially easy $(M=3.19 ; 64.2 \%)$, always instructive $(M=4.51 ; 62.3 \%)$, always useful $(M=4.47 ; 56.6 \%)$, always flexible $(M=4.43 ; 64.2 \%)$, and usually advantageous $(M=3.83 ; 41.5 \%)$. On the other hand, the students' opinions about the FLM in terms of out-of-class practices were as follows: generally effective $(M=3.42 ; 30.2 \%)$, usually fun $(M=3.66 ; 43.4 \%)$, partially simple $(M=3.77 ; 50.9 \%)$, usually tiring $(M=2.94 ; 39.6 \%)$, partially different $(M=3.58 ; 41.5 \%)$, partially easy $(M=2.92 ; 26.4 \%)$, partially instructive $(M=3.75 ; 41.5 \%)$, generally helpful $(M=3.85 ; 20.9 \%)$, always flexible $(M=4.40 ; 52.8 \%)$, and usually advantageous $(M=3.62 ; 35.8 \%)$. In line with these results, emotional semantic orientations of gifted students toward the FLM are given in Fig. 7.

\subsection{Gifted Students' Opinions about the FLM}

Within the scope of the research, answers to the question "What are the opinions of gifted students about FLM?" were sought. Table 5 presents the categories and codes that were formed based on the students' opinions on the effectiveness of FLM in learning.

As seen in Table 5, a significant portion of the participants had the idea that the FLM was an effective learning model. In this context, five participants stated that the FLM increased learning. On this issue, P1 said, "Yes, it is very effective. As we get preliminary knowledge about the subject in advance, we learn the subject better in the lesson." and P4 said, "Yes, I think it is effective because it helps us understand the lesson better." Of the participants, three expressed their opinions about the FLM by saying that it helped them come to the lesson in a properly prepared way. For example, P8 said, "Yes, this model is positively effective in learning. I understand the lesson better when I go to the lesson after 
Table 4 Descriptive values regarding the data obtained from the scale

\begin{tabular}{|c|c|c|c|c|c|c|c|c|c|c|c|c|c|}
\hline \multirow[t]{2}{*}{ Semantic expressions } & \multirow[b]{2}{*}{$\mathrm{n}$} & \multirow[b]{2}{*}{$M$} & \multirow[b]{2}{*}{ SD } & \multicolumn{2}{|c|}{ Always } & \multicolumn{2}{|c|}{ Usually } & \multicolumn{2}{|c|}{ Partially } & \multicolumn{2}{|c|}{ Usually } & \multicolumn{2}{|c|}{ Always } \\
\hline & & & & $\mathrm{f}$ & $\%$ & $\mathrm{f}$ & $\%$ & $\mathrm{f}$ & $\%$ & $\mathrm{f}$ & $\%$ & $\mathrm{f}$ & $\%$ \\
\hline Effective-ineffective & 53 & 4.28 & .71 & 23 & 43.4 & 22 & 41.5 & 8 & 15.1 & - & - & - & - \\
\hline Fun-boring & 53 & 3.70 & .77 & 7 & 13.2 & 26 & 49.0 & 17 & 32.1 & 3 & 5.7 & - & - \\
\hline Simple-complex & 53 & 3.57 & .69 & 5 & 9.4 & 21 & 39.6 & 26 & 49.1 & 1 & 1.9 & - & - \\
\hline Not tiring-tiring & 53 & 3.72 & .88 & 13 & 24.5 & 14 & 26.4 & 24 & 45.3 & 2 & 3.8 & - & - \\
\hline Different-ordinary & 53 & 4.32 & .82 & 29 & 54.8 & 12 & 22.6 & 12 & 22.6 & - & - & - & - \\
\hline Easy-difficult & 53 & 3.19 & .62 & 1 & 1.9 & 13 & 24.5 & 34 & 64.2 & 5 & 9.4 & & \\
\hline Instructive-not instructive & 53 & 4.51 & .69 & 33 & 62.3 & 14 & 26.4 & 6 & 11.3 & - & - & - & - \\
\hline Beneficial-detrimental & 53 & 4.47 & .69 & 30 & 56.6 & 19 & 35.8 & 3 & 5.7 & 1 & 1.9 & - & - \\
\hline Flexible-rigid & 53 & 4.43 & .88 & 34 & 64.2 & 11 & 20.8 & 5 & 9.4 & 3 & 5.7 & - & - \\
\hline Advantageous-disadvantageous & 53 & 3.83 & .82 & 12 & 22.6 & 22 & 41.5 & 17 & 32.1 & 2 & 3.8 & - & - \\
\hline \multicolumn{14}{|l|}{ FLM for out-of- class applications } \\
\hline \multirow[t]{2}{*}{ Semantic Expressions } & \multirow[b]{2}{*}{$\mathrm{n}$} & \multirow[b]{2}{*}{$M$} & \multirow[b]{2}{*}{ SD } & \multicolumn{2}{|c|}{ Always } & \multicolumn{2}{|c|}{ Usually } & \multicolumn{2}{|c|}{ Partially } & \multicolumn{2}{|c|}{ Usually } & \multicolumn{2}{|c|}{ Always } \\
\hline & & & & $\mathrm{f}$ & $\%$ & $\mathrm{f}$ & $\%$ & $\mathrm{f}$ & $\%$ & $\mathrm{f}$ & $\%$ & $\mathrm{f}$ & $\%$ \\
\hline Effective-ineffective & 53 & 3.42 & 1.26 & 12 & 22.6 & 16 & 30.2 & 12 & 22.6 & 8 & 15.1 & 5 & 9.4 \\
\hline Fun-boring & 53 & 3.66 & .96 & 10 & 18.9 & 23 & 43.4 & 12 & 22.6 & 8 & 15.1 & - & - \\
\hline Simple-complex & 53 & 3.77 & .86 & 15 & 28.3 & 11 & 20.8 & 27 & 50.9 & - & - & - & - \\
\hline Not tiring-tiring & 53 & 2.94 & 1.00 & 4 & 7.5 & 12 & 22.6 & 15 & 28.3 & 21 & 39.6 & 1 & 1.9 \\
\hline Different-ordinary & 53 & 3.58 & .96 & 11 & 20.8 & 15 & 28.3 & 22 & 41.5 & 4 & 7.5 & 1 & 1.9 \\
\hline Easy-difficult & 53 & 2.92 & 1.26 & 7 & 13.2 & 11 & 20.8 & 14 & 26.4 & 13 & 24.5 & 8 & 15.1 \\
\hline Instructive-not instructive & 53 & 3.75 & .93 & 15 & 28.3 & 13 & 24.5 & 22 & 41.5 & 3 & 5.7 & - & - \\
\hline Beneficial-detrimental & 53 & 3.85 & .84 & 11 & 20.8 & 27 & 20.9 & 11 & 20.8 & 4 & 7.5 & - & - \\
\hline Flexible-rigid & 53 & 4.40 & .74 & 28 & 52.8 & 19 & 35.8 & 5 & 9.4 & 1 & 1.9 & - & - \\
\hline Advantageous-disadvantageous & 53 & 3.62 & 1.00 & 13 & 13.2 & 14 & 35.8 & 19 & 26.4 & 7 & 24.5 & - & - \\
\hline
\end{tabular}

doing preliminary study." Similarly, three participants noted that the subjects covered in the lessons where the FLM was implemented could be repeated. For example, P7 said, "Yes, because I can learn faster this way. I can watch the video over and over again." P5 said that the FLM was an effective model and that it saved time; however, P2 stated that the model was not effective, and especially, that it caused some problems in out-of-class practices. Table 6 presents the categories and codes created in line with examining the opinions of the students about whether the FLM was fun or not.

According to Table 6, two of the participants said that the FLM was entertaining while learning and that it was fun due to its flexible learning environment. P6 said, "I think it is fun. I think the flipped learning model makes us learn by both informing and entertaining.". P11 said, "Yes, I think it is fun. If we do not want to listen to a lesson at that moment, we can listen to it at another time." P1 stated that the FLM was fun because learning with the FLM was easy. P1 said, "Yes, it's fun. Learning is fun because we study the subject beforehand and have an opinion on it." P4, on the other hand, stated that the FLM was fun in terms of out-of-class practices and said, "Yes, I think it is fun because whenever 


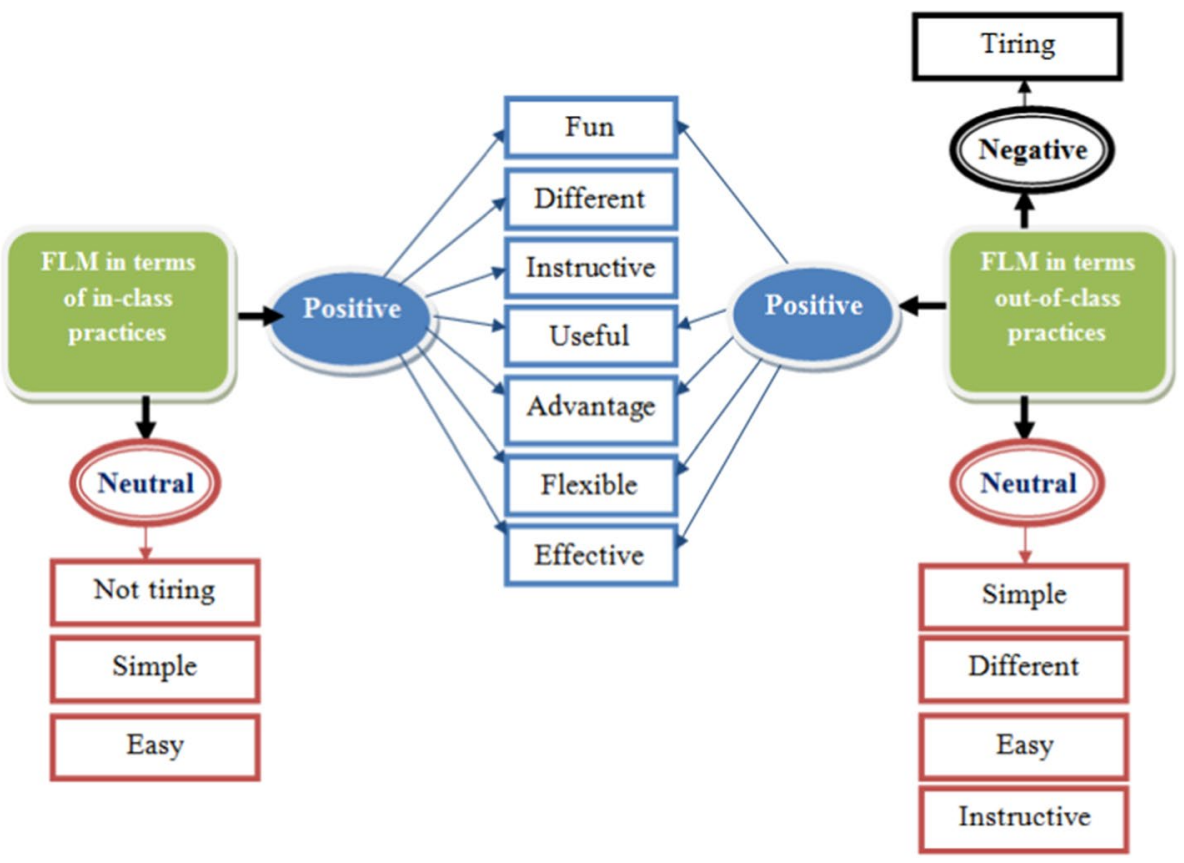

Fig. 7 Emotional semantic values added to the FLM

Table 5 Student views on the effectiveness of the FLM

Table 6 The views of the students about whether FLM was fun or not

\begin{tabular}{|c|c|}
\hline Categories & Codes \\
\hline \multirow[t]{4}{*}{ Effective } & Increases learning (P1, P4, P6, P7, P9) \\
\hline & $\begin{array}{l}\text { It helps them come to the lesson in a properly } \\
\text { prepared way. (P3, } \mathrm{P} 8, \mathrm{P} 10)\end{array}$ \\
\hline & The opportunity to repeat the lesson (P7, P11, P12) \\
\hline & It saves time (P5) \\
\hline Ineffective & There may be problems (P2) \\
\hline
\end{tabular}

\begin{tabular}{ll}
\hline Categories & Codes \\
\hline Fun & Entertains while learning (P3, P6) \\
& Provides a flexible learning environment (P11, P12) \\
& Makes learning easier (P1) \\
& Exciting for out-of-class applications (P4) \\
& Efficient and easy (P5) \\
& Different (P7) \\
& Possibility to practice more (P8) \\
& The model is not fun (P2) \\
\hline
\end{tabular}


Table 7 Student views on the advantages and disadvantages of the science course taught using the FLM

\begin{tabular}{ll}
\hline Categories & Codes \\
\hline Advantageous & The opportunity to repeat the lesson (P4, P7, P10, P11, P12) \\
& More activities can be done in the lesson (P2, P5, P8) \\
& Increases learning (P3, P5, P6) \\
& Coming ready to class (P1, P9) \\
Disadvantageous & There is a problem in instant communication (P7, P11) \\
& I can forget the subjects (P2, P5) \\
\hline
\end{tabular}

Table 8 Students' views on whether the FLM was different and flexible

\begin{tabular}{ll}
\hline Categories & Codes \\
\hline Different/Flexible & In terms of learning $(\mathrm{P} 1, \mathrm{P} 11, \mathrm{P} 10)$ \\
& In terms of teaching the lesson $(\mathrm{P} 4, \mathrm{P} 6, \mathrm{P} 7)$ \\
& In terms of time management $(\mathrm{P} 2, \mathrm{P} 5)$ \\
& In terms of course preparation $(\mathrm{P} 1)$
\end{tabular}

our teacher sends a new video, I get excited and enjoy watching it." One participant, however, found the FLM to be effective, easy, different, and enjoyable as it allowed opportunities to practice. P2 stated that the model was not fun, but it was fun in terms of activities. "I don't find the flipped learning model much fun, but I find the activities that we did fun." However, despite stating that the model was partially fun, P9 did not exactly explain why. Table 7 presents the categories and codes created based on the students' views on the advantages and disadvantages of the science course taught using the FLM.

Based on Table 7, a significant portion of the participants found it an advantage to have the possibility of repetition in science lessons taught using the FLM. For example, P4 said, "We can watch that lesson video again in order not to forget the subject." P7 said, "I can watch the video over and over again.". Three of the participants thought that carrying out more activities in science courses was an advantage of the FLM. Accordingly, P5 said, "I can easily access the delivered materials and can understand the lesson better; we can do activities after the lesson." Furthermore, as an advantage of the FLM, three participants stated that the method increased their learning and two participants said that students came to the lesson prepared. For example, P6 said, "I think it is advantageous in every respect as I learned everything very well." and P9 noted, "I understood the subject better when I went to the lesson after studying beforehand." Two participants each expressed their views on the disadvantages of using the FLM in science lessons. Stating that there was a problem in instant communication with the teacher of the lesson especially in out-of-class practices, P11 said, "If I cannot understand the subject during the activity, I have to ask my teacher; however, as my teacher is not with me, I have to wait until tomorrow." Drawing attention to the fact that the subjects covered can be forgotten, P2 said, "Sometimes I forget while listening to the lesson; I cannot solve the questions." Table 8 presents the categories and codes created based on the opinions of the students regarding whether the FLM was different and more flexible than other teaching methods-strategies.

According to Table 8, three participants expressed the view that the FLM was different in terms of learning. For example, P1 said, "Yes. It is easy to understand the subject." 
Regarding out-of-class activities, P10 said, "Yes. It is because we can comprehend the subjects beforehand." Likewise, three participants stated that the FLM was different and flexible in terms of teaching the course. For example, P4 said, "We used to study a subject at school, and we used to discuss the same subject in our next lesson to reinforce it; however, there is no such a thing in the FLM. We watch the video that our teacher prepared and delivered to us beforehand. We reinforce the subject in our school.". In addition, two participants stated that the FLM was different in terms of time management and one participant said it was different in terms of preparation for the class. For example, P5 said, "Yes, it is because I can watch whenever I want and when I do not understand the subject, I can watch it again. It's not like the way I am accustomed to in the school; it's different as I do the timing myself." and pointed out that the FLM was different from other methods in terms of time management. P3, P8, and P9 were of the same mind that the FLM was different, but they did not explain why this was so. P12 stated that the FLM was not different from other methods.

When the participants were asked whether they had any difficulties in the science course taught according to the FLM, a significant portion of them $(n=9)$ stated that they had not experienced any difficulties. P7 and P11 stated that they had difficulties because they could not ask the teacher instant questions during out-of-class practices. P11 said, "I experienced it sometimes. If I haven't understood the subject even after I have listened to it two or three times, I have a lot of questions in my mind and I want to ask my teacher immediately."

\subsection{Examination of the Emotional Semantic Orientation of Gifted Students toward the FLM According to Gender}

In the study, an answer to the question "Do the emotional semantic orientations of gifted students toward FLM show a significant difference in terms of gender?" was sought and in this context, an independent samples t-test was conducted. Table 9 presents the results of the analysis.

Levene's test results indicated that the variances of the groups were equally distributed $(p>0.05)$. There was no significant difference between the emotional semantic orientations of the female and male participants in terms of in-class practices $(p>0.05)$. Nevertheless, a significant difference was found between the scores of female and male participants in terms of the effective-ineffective $[(\mathrm{t}(51)=2.397 ; p=0.020<0.05)]$ and fun-boring adjective pairs $[(\mathrm{t}(51)=-2.147 ; p=0.037<0.05)]$ in terms of out-of-class practices. This difference was in favor of male and female participants for the effective-ineffective and funboring adjective pairs, respectively.

\section{Discussion and Conclusion}

This study aimed to examine emotional semantic orientations of gifted students toward the FLM and it was conducted with 53 gifted students. The participants deemed the to be FLM fun, different, instructive, useful, advantageous, flexible, and effective in terms of in-class practices. This result was also supported by the answers given by the students to the questions in the questionnaire. A great majority of the students stated that the FLM was an effective model as it increased learning, provided more possibilities for repetition and saved time. They also found the FLM to be fun due to its features such as facilitating learning, being flexible, and providing opportunities for practice. Moreover, most of the 
Table 9 Independent Sample t Test Results in Terms of Gender

\begin{tabular}{|c|c|c|c|c|c|c|c|c|}
\hline & Semantic expressions & Gender & $\mathrm{N}$ & $M$ & SD & df & $\mathrm{t}$ & $p$ \\
\hline \multirow{20}{*}{$\begin{array}{l}\text { FLM for } \\
\text { In-class } \\
\text { applica- } \\
\text { tions }\end{array}$} & \multirow[t]{2}{*}{ Effective-ineffective } & Male & 23 & 4.17 & .717 & \multirow[t]{2}{*}{51} & \multirow[t]{2}{*}{-.969} & \multirow[t]{2}{*}{.33} \\
\hline & & Female & 30 & 4.37 & .718 & & & \\
\hline & \multirow[t]{2}{*}{ Fun-boring } & Male & 23 & 3.74 & .619 & \multirow[t]{2}{*}{51} & \multirow[t]{2}{*}{.335} & \multirow[t]{2}{*}{.73} \\
\hline & & Female & 30 & 3.67 & .884 & & & \\
\hline & \multirow[t]{2}{*}{ Simple-complex } & Male & 23 & 3.70 & .703 & \multirow[t]{2}{*}{51} & \multirow[t]{2}{*}{1.196} & \multirow[t]{2}{*}{.23} \\
\hline & & Female & 30 & 3.47 & .681 & & & \\
\hline & \multirow[t]{2}{*}{ Not tiring-tiring } & Male & 23 & 3.52 & .790 & \multirow[t]{2}{*}{51} & \multirow[t]{2}{*}{-1.419} & \multirow[t]{2}{*}{.16} \\
\hline & & Female & 30 & 3.87 & .937 & & & \\
\hline & \multirow[t]{2}{*}{ Different-ordinary } & Male & 23 & 4.39 & .839 & \multirow[t]{2}{*}{51} & \multirow[t]{2}{*}{.540} & \multirow[t]{2}{*}{.59} \\
\hline & & Female & 30 & 4.27 & .828 & & & \\
\hline & \multirow[t]{2}{*}{ Easy-difficult } & Male & 23 & 3.30 & .635 & \multirow[t]{2}{*}{51} & \multirow[t]{2}{*}{1.190} & .23 \\
\hline & & Female & 30 & 3.10 & .607 & & & \\
\hline & Instructive-not instructive & Male & 23 & 4.30 & .765 & 51 & 1.924 & .06 \\
\hline & & Female & 30 & 4.67 & .606 & & & \\
\hline & Beneficial-detrimental & Male & 23 & 4.39 & .783 & 51 & -.733 & .46 \\
\hline & & Female & 30 & 4.53 & .629 & & & \\
\hline & Flexible-rigid & Male & 23 & 4.52 & .846 & 51 & 626 & .53 \\
\hline & & Female & 30 & 4.37 & .928 & & & \\
\hline & Advantageous-disadvantageous & Male & 23 & 3.83 & .834 & 51 & -.031 & .97 \\
\hline & & Female & 30 & 3.83 & .834 & & & \\
\hline FLM for out- & Effective-ineffective & Male & 23 & 3.87 & .968 & 51 & 2.397 & $.02 *$ \\
\hline of- class & & Female & 30 & 3.07 & 1.36 & & & \\
\hline $\begin{array}{l}\text { appinc- } \\
\text { tions }\end{array}$ & Fun-boring & Male & 23 & 3.35 & .832 & 51 & -2.147 & $.03 *$ \\
\hline & & Female & 30 & 3.90 & .995 & & & \\
\hline & Simple-complex & Male & 23 & 3.83 & .834 & 51 & .382 & .70 \\
\hline & & Female & 30 & 3.73 & .907 & & & \\
\hline & Not tiring-tiring & Male & 23 & 3.17 & 1.11 & 51 & 1.474 & .14 \\
\hline & & Female & 30 & 2.77 & .898 & & & \\
\hline & Different-ordinary & Male & 23 & 3.43 & 1.03 & 51 & -.987 & .32 \\
\hline & & Female & 30 & 3.70 & .915 & & & \\
\hline & Easy-difficult & Male & 23 & 3.00 & 1.16 & 51 & .376 & .70 \\
\hline & & Female & 30 & 2.87 & 1.35 & & & \\
\hline & Instructive-not instructive & Male & 23 & 3.83 & .887 & 51 & .481 & .63 \\
\hline & & Female & 30 & 3.70 & .988 & & & \\
\hline & Beneficial-detrimental & Male & 23 & 3.74 & .810 & 51 & -.831 & .41 \\
\hline & & Female & 30 & 3.93 & .868 & & & \\
\hline & Flexible-rigid & Male & 23 & 4.35 & .885 & 51 & -.412 & .68 \\
\hline & & Female & 30 & 4.43 & .626 & & & \\
\hline & Advantageous-disadvantageous & Male & 23 & 3.57 & .945 & 51 & -.361 & .71 \\
\hline & & Female & 30 & 3.67 & 1.06 & & & \\
\hline
\end{tabular}

$p^{*}<.05$ 
students stated that the FLM had many advantages. They evaluated the advantages of the FLM in terms of providing the opportunity for repetition, making more activities in inclass practices, and increasing learning. When their opinions on whether the FLM was different and more flexible than other teaching methods were examined, a significant portion of the students stated that the model was different and flexible. The participants evaluated the difference and flexibility of the FLM in terms of learning-teaching subjects and time management during in-class activities. Accordingly, it can be concluded that the participating gifted students had a positive attitude toward the in-class practices of the FLM. The fact that more emphasis was given to experimental studies in in-class practices, that group work was carried out as well as individual studies, and that gifted students who learn faster than their peers were more willing for high-level practices in class instead of just teaching the subjects may have been effective in students' positive attitudes toward the FLM. This result is similar to those obtained from some studies conducted with different student groups (Enfield, 2013; Hung, 2015; Johnston, 2017; Lucke et al., 2016; Mason et al., 2013; Singay, 2020; Snyder et al., 2014; Su \& Chen, 2018). For example, Johnston (2017) carried out a study with university students and found that the students developed a positive attitude toward the FLM. Similarly, Quyen and Loi (2018) investigated students' attitudes toward the FLM and concluded that the students had a positive attitude toward the FLM. Nouri (2016) stated that many of the students who participated in the study improved a positive attitude towards FLM because FLM increased student motivation and learning success. Helan and Anbazhagan (2021) emphasized that after the COVID-19 pandemic, the interest in FLM increased, and students showed a positive attitude towards FLM. In the current study, it is seen that students come ready for the activities to be done in the classroom (e.g., Grypp \& Luebeck, 2015), interact with their teachers and friends in the classroom environment (e.g., Chen, 2016), have group discussions in the classroom (e.g., Kettle, 2013) and peer learning is at the forefront (e.g., Mazur et al., 2015) is thought to be effective in the positive attitudes of the participants towards in-class practices. Therefore, the reasons for the semantic orientation of students towards FLM, in which they actively take part in classroom practices, might be the reasons mentioned above. However, it was determined that the participants regarded the FLM as partially tiring, complicated, and difficult in terms of in-class activities. Students are expected to participate in individual and group-work studies and to be actively involved in the learning process in in-class practices in the FLM where knowledge transfer is carried out of the classroom as part of the teaching process (Abeysekera \& Dawson, 2015; Chen, 2016; Lestari, 2021). This could have caused the students to find in-class activities tiring and difficult. This result parallels some studies in the literature (Chen, 2016; Love et al., 2014; Palmer, 2015). For example, Palmer (2015) reported that students expressed similar reasons and stated that the FLM was not suitable for them. DeSantis et al. (2015) stated that students' satisfaction with FLM is low; Chen (2016) mentioned that students were resistant to studying the subject before the lesson and could not indicate the desired success in classroom practices. Based on this finding, it is necessary to determine the situations where students have difficulties in in-class practices in the lessons taught according to the FLM and to develop solutions for these situations.

The current study found that the participants regarded the FLM as fun, useful, advantageous, flexible, and effective in terms of out-of-class practices. In examining the answers given to the open-ended questions, some of the students were of the opinion that the FLM was effective and advantageous in terms of allowing them to come to the lesson prepared and to revise or repeat the subjects more. Additionally, a significant portion of the students stated that the FLM was fun because it was flexible, different, and exciting in terms of out-of-class activities. However, according to the students, the 
FLM was partially simple, different, easy, and instructive. In line with this result, it can be concluded that gifted students also wanted to continue their education within the traditional teaching method they are used to. This result is also supported by the fact that students regarded out-of-class practices as tiring. The relevant literature has reported that many factors play a role in this situation. Factors such as students' being resistant to this new model and coming to the class unprepared (McCarthy, 2016), not giving necessary support to students while conducting lessons in accordance with the FLM (Kim et al., 2014), teachers' inadequacy for the model (Peled et al, 2015), and students' low self-regulated learning skills (Talbert, 2014) can affect their attitudes toward the FLM and affect their prejudice against this model. Tarigan (2021) stated that teachers should be aware of their competence to use this model before using FLM because the teacher factor affects students' attitudes towards FLM. In addition, it can be said that the course contents used in out-of-class practices are also effective on students' attitudes. Moreover, Adedoja (2016) mentioned that although students' attitudes towards FLM are positive, the large size of videos used in out-of-class applications poses a problem for them. Long et al. (2016) suggested that the videos sent to students in out-of-class practices should be short and interesting. Similarly, Ramírez et al. (2014) emphasized that the videos should be short and suitable for the students' developmental levels. Mkhymryahya et al. (2021), on the other hand, demonstrated the importance of preparing the contents with teacher groups in out-of-class practices. Furthermore, the students' lack of self-discipline and motivation might cause them not to fulfil the tasks given in outof-class practices and not to participate sufficiently in classroom practices (Sue \& Hou, 2017). Therefore, students and teachers' readiness for this model should be determined before conducting the lessons in accordance with the FLM (Durak, 2017). In addition, while the lessons suitable for FLM are being taught, especially with the younger age group students, moving the school environment to home may have caused them to have uninstructive, difficult, complex, and non-different semantic orientations towards learning. Moreover, the fact that students devote their free time to the learning process might be the reason why they have such negative orientations.

No significant difference was found between the emotional semantic orientations of the female and male participants in terms of in-class practices. This is an expected finding in terms of gender equality. However, there was a significant difference between the scores obtained from the answers given for the effective-ineffective adjective pair in favor of male participants for out-of-class practices. In line with this result, it can be concluded that male participants regarded out-of-class practices of the FLM to be more effective in learning. The male students' greater tendency to use technology than female students could have played a role in this difference. Baran and Ata (2013) examined the frequency of technology use of students in terms of gender and found that the frequency and skill levels of males using technologies suitable for the FLM were significantly higher than those of females, which supports the result obtained from the present study. On the other hand, a significant difference in favor of female participants was found between the scores obtained from the answers given by the female and male participants to the fun-boring adjective pair for out-of-class practices. Today, as a result of the introduction of blended learning models in learning environments, the use of technology has increased and gender difference in technology usage has begun to draw researchers' attention (Siann et al., 1990). However, there are few studies examining the attitudes of male and female students toward the FLM, which also includes the use of technology. Sağlam and Arslan (2018) suggested that more studies be conducted on the effect of the gender variable of FLM. Therefore, it is important 
to examine attitudes of male and female students at different education levels toward the FLM.

\subsection{Limitations and Suggestions}

The current study has a few limitations. First, the study had a relatively small sample size. The sample can be increased to reveal more deeply how the emotional semantic orientations of gifted students in the lessons taught according to the flipped learning model (Lestari, 2021). Secondly, a science course in accordance with the FLM, covering a 10-week process, was conducted with gifted students. Studies covering a more extended period should be conducted to determine the emotional semantic orientations of the students regarding the model. In this context, Lo and Hew (2017) suggested examining the effectiveness of FLM in a longer time frame. Third, in this study, the qualitative data were collected with a single measurement tool. In this context, it can be used as data collection tools such as interviews and classroom observations to gain more detailed qualitative data. Studies integrating hybrid learning approaches such as the FLM and evaluating students' cognitive and affective developments in other disciplines and subjects should be conducted to obtain more data on this approach. As a solution to students' difficulties in learning out of school, 'an online discussion platform' or a sub-tab under the heading 'frequently asked questions about the subject' on a similar web page should be opened for out-of-school education content in the FLM to guide students for their questions on the subject. Furthermore, studies in which different modern teaching methods or strategies (STEM, argumentation, project-based learning, etc.) are blended should be conducted for in-class practices in the FLM. Finally, to increase the awareness and competence of teachers, who are the implementers of hybrid teaching approaches such as the FLM, close cooperation should be established between universities and schools and in-service training programs should be organized.

Data Availability This manuscript has no associated data or the data will not be deposited.

\section{References}

Abeysekera, L., \& Dawson, P. (2015). Motivation and cognitive load in the flipped classroom: Definition, rationale and a call for research. Higher Education Research \& Development, 34(1), 1-14. https://doi. org/10.1080/07294360.2014.934336

Adedoja, G. (2016). Pre-service teachers' challenges and attitude toward the flipped classroom. African Educational Research Journal, 4(1), 13-18.

Al Mamun, M. A., Azad, M. A. K., \& Boyle, M. (2021). Review of flipped learning in engineering education: Scientific mapping and research horizon. Education and Information Technologies. https://doi. org/10.1007/s10639-021-10630-Z

Al-Harbi, S. S., \& Alshumaimeri, Y. A. (2016). The flipped classroom impact in grammar class on efl Saudi secondary school students' performances and attitudes. English Language Teaching, 9(10), 60-80.

Ataman, A. (2009). Special needs children and introduction of special education. Gifted and talented children. Gündüz Education and Publishing.

Baran, B., \& Ata, F. (2013). University students' use, skills and utilization of web 2.0 technologies. Education and Science, 38(169), 192-208.

Bates, J. E., Almekdash, H., \& Gilchrest-Dunnam, M. J. (2017). The flipped classroom: A brief, brief history. In Green L. Santos, J. Banas, \& R. Perkins (Eds.), The flipped college classroom, educational 
communications and technology: issues and innovations. Cham: Springer. https://doi.org/10.1007/ 978-3-319-41855-1_1

Behmanesh, F., Bakouei, F., Nikpour, M., \& Parvaneh, M. (2020). Comparing the effects of traditional teaching and flipped classroom methods on midwifery students' practical learning: The Embedded mixed method. Technology, Knowledge and Learning, 1-10.

Bell, M. R. (2015). An investigation of the impact of a flipped classroom instructional approach on high school students' content knowledge and attitudes toward the learning environment. Brigham Young University.

Belovitskay, S., Guseva, T., Demicheva, D., Shatokhina, I., \& Shcherbina, E. (2021). Blended learning technology" Flipped Class" in the system of higher vocational education. In E3S Web of Conferences. EDP Sciences, 273, p. 12003

Bergmann, J., \& Sams, A. (2012). Flip your classroom: Reach every student in every class every day. Washington, DC: International Society for Technology in Education.

Betaubun, M. (2021). The students' attitude and learning experience toward flipped classroom implementation during COVID-19 outbreak: A survey study. Jurnal Pendidikan Progresif, 11(1), 54-62.

Bin-Hady, W. R. A., \& Hazaea, A. N. (2021). EFL students' achievement and attitudes towards flipped pronunciation class: correlational study. PSU Research Review. https://doi.org/10.1108/ PRR-09-2020-0029

Birgili, B., Seggie, F. N., \& Oğuz, E. (2021). The trends and outcomes of flipped learning research between 2012 and 2018: A descriptive content analysis. Journal of Computers in Education, 8(3), 365-394.

Bishop, J. L., \& Verleger, M. A. (2013). The flipped classroom: A survey of the research. In ASEE National Conference Proceedings, Atlanta, GA 30(9): 1-18

Broderick, J. E. (2016). Flipped classrooms as an experiential learning strategy: How do faculty adapt to teaching with instructional technology?. Johnson \& Wales University. ProQuest Dissertations Publishing.

Çakır, E., \& Yaman, S. (2018). The effect of flipped classroom model on students' science success and computational thinking skills. Gazi University Journal of Gazi Educational Faculty, 38(1), 75-99.

Cashin, M. (2016). The effect of flipped classrooms on elementary students' reading scores. Arizona: Northcentral University.

Cavilla, D. (2019). Maximizing the potential of gifted learners through a developmental framework of affective curriculum. Gifted Education International, 35(2), 136-151. https://doi.org/10.1177/ 0261429418824875

Ceylaner, S. (2016). Effects of flipped classroom on students' self- directed learning readiness and attitudes towards English lesson in 9th grade English language teaching (Master's thesis). Mersin University, Mersin.

Chao, C. Y., Chen, Y.-T., \& Chuang, K. Y. (2015). Exploring students' learning attitude and achievement in flipped learning supported computer aided design curriculum: A study in high school engineering education. Computer Applications in Engineering Education, 23(4), 514-526. https://doi.org/ $10.1002 /$ cae. 21622

Chen, L. L. (2016). Impacts of flipped classroom in high school health education. Journal of Educational Technology Systems, 44(4), 411-420.

Cheng, L., Ritzhaupt, A. D., \& Antonenko, P. (2019). Efects of the fipped classroom instructional strategy on students' learning outcomes: A meta-analysis. Educational Technology Research and Development, 67(4), 793-824. https://doi.org/10.1007/s11423-018-9633-7

Chung, E. J., \& Lee, B. H. (2018). The effects of flipped learning on learning motivation and attitudes in a class of college physical therapy students. Journal of Problem-Based Learning, 5(1), 29-36.

Corbin, J., \& Strauss, A. (2007). Basics of qualitative research: Techniques and procedures for developing grounded theory. Sage.

Creswell, J. W. (2014). Qualitative, quantitative and mixed methods approaches. Sage.

Çukurcubaş1, B. (2016). Examine the effect of the problem based learning activities supported via flipped classroom and lego-logo practices on the high school students' success and their motivation. Turkey: Sakarya University.

Davies, R. S., Dean, D. L., \& Ball, N. (2013). Flipping the classroom and instructional technology integration in a collegelevel information systems spreadsheet course. Educational Technology Research and Development, 61(4), 563-580. https://doi.org/10.1007/s11423-013-9305-6

Desantis, J., Van-Curen, R., Putsch, J., \& Metzger, J. (2015). Do students learn more from a flip? An exploration of the efficacy of flipped and traditional lessons. Journal of Interactive Learning Research, 26(1), 39-63. 
Durak, Y. H. (2017). Turkish adaptation of the flipped learning readiness scale for middle school students. Bartin University Journal of Faculty of Education, 6(3), 1056-1068. https://doi.org/10. 14686/buefad.328826

EduTrends. (2016). Gamification. Observatory of educational innovation. Tecnológico de Monterrey. Retrieved from http://observatory.itesm.mx/edu-trends-gamification

Ekici, G., Kurt, H., \& Gökmen, A. (2015). The values attributed to computer by teacher candidates according to emotional semantic difference. Kastamonu Education Journal, 23(1), 71-86.

Enfield, J. (2013). Looking at the impact of the flipped classroom model of instruction on undergraduate multimedia students at CSUN. Tech Trends, 57(6), 14-27. https://doi.org/10.1007/ s11528-013-0698-1

Fard, Z. R., Shahrokhi, M., \& Talebinejad, M. R. (2021). The effect of flipped classroom on iranian esp students' vocabulary learning, retention and attitude. International Journal of Foreign Language Teaching and Research, 9(35), 115-129.

Fernández-Martín, F. D., Romero-Rodríguez, J. M., Gómez-García, G., \& Ramos Navas-Parejo, M. (2020). Impact of the flipped classroom method in the mathematical area: A systematic review. Mathematics, 8(12), 1-11.

Fraenkel, J. R., \& Wallen, N. E. (2006). How to design and evaluate research in education 6. McGraw-Hill.

Fulton, K. (2012). Upside down and inside out: Flip your classroom to improve student learning. Learning and Leading with Technology, 39(8), 13-17.

Gallegher, A., \& De Lisi, R. (1994). Gender differences in scholastics aptitude test: Mathematics problem solving among high-ability students. Journal of Educational Psychology, 86(2), 204-211. https://doi.org/10.1037/0022-0663.86.2.204

Gannod, G., Burge, J., \& Helmick, M. (2008). Using the inverted classroom to teach software engineering. In $2008 \mathrm{ACM} / \mathrm{IEEE}$ 30th International Conference on Software Engineering, IEEE, pp. $777-786$.

George, D., \& Mallery, P. (2001). SPSS for Windows. Step by step (3rd ed.). Allyn \& Bacon.

Gerstein, J. (2012). The flipped classroom model: A full picture [EB/OL]. Retrieved from https://userg eneratededucation.wordpress.com/2011/06/13/the-flipped-classroom-model-a-full-picture/

Ghanaat, H., \& Habibzadeh, A. (2021). Analyzing the impact of flipped classroom on students' mathematical academic achievement and attitude towards mathematics. Research in Curriculum Planning, 17(67), 183-196.

Grypp, L., \& Luebeck, J. (2015). Rotating solids and flipping instruction. Mathematics Teacher, 109(3), 186-193.

Güç, F. (2017). The effect of the flipped classroom practice on the rational numbers and operations with rational numbers. Amasya University.

Halili, S. H., Mohsin, N., \& Razak, R. A. (2021). Student perceptions towards the use of the mobile flipped classroom approach. International Journal of Web-Based Learning and Teaching Technologies (IJWLTT), 16(6), 1-13.

Hamdan, N., McKnight, P., McKnight, K., \& Arfstrom, K. M. (2013). The flipped learning model: A white paper based on the literature review titled a review of flipped learning. Flipped Learning Network/Pearson/George Mason University.

Helan, C., \& Anbazhagan, K. (2021). Using flipped classroom technique on online teaching platform during COVID-19. Psychology and Education Journal, 58(1), 5422-5430.

Helsper, E. J., \& Eynon, R. (2010). Digital natives: Where is the evidence? British Educational Research Journal, 36(3), 503-520. https://doi.org/10.1080/01411920902989227

Huang, H. L., Chou, C. P., Leu, S., You, H. L., Tiao, M. M., \& Chen, C. H. (2020). Effects of a quasiexperimental study of using flipped classroom approach to teach evidence-based medicine to medical technology students. BMC Medical Education, 20(1), 1-9.

Huang, H. M., Rauch, U., \& Liaw, S. S. (2010). Investigating learners' attitudes toward virtual reality learning environments: Based on a constructivist approach. Computers \& Education, 55(3), 1171-1182.

Hubers, M. D., \& D. Endedijk M, Van Veen K. (2020). Effective characteristics of professional development programs for science and technology education. Professional Development in Education. https://doi.org/10.1080/19415257.2020.1752289

Hung, H. (2015). Flipping the classroom for English language learners to foster activlearning. Computer Assisted Language Learning, 28(1), 81-96. https://doi.org/10.1080/09588221.2014.967701

Hwang, G. J., Chang, S. C., Song, Y., \& Hsieh, M. C. (2021). Powering up flipped learning: An online learning environment with a concept map-guided problem-posing strategy. Journal of Computer Assisted Learning, 37(2), 429-445. 
Ivankova, N. V., Creswell, J. W., \& Stick, S. L. (2006). Using mixed-methods sequential explanatory design: From theory to practice. Field Methods, 18(1), 3-20. https://doi.org/10.1177/1525822X05282260

Jdaitawi, M. (2020). Does flipped learning promote positive emotions in science education? A comparison between traditional and flipped classroom approaches. Electronic Journal of e-Learning, $18(6), 516-524$.

Jiang, L., Meng, H., \& Zhou, N. (2021). English learners' readiness for online flipped learning: Interrelationships with motivation and engagement, attitude, and support. Language Teaching Research. https://doi.org/10.1177/13621688211027459

Johnson, R. B., Onwuegbuzie, A. J., \& Turner, L. A. (2007). Toward a definition of mixed methods research. Journal of Mixed Methods Research, 1(2), 112-133.

Johnston, B. M. (2017). Implementing a flipped classroom approach in a university numerical methods mathematics course. International Journal of Mathematical Education in Science and Technology, 48(4), 485-498. https://doi.org/10.1080/0020739X.2016.1259516

Kettle, M. (2013). Flipped physics. Physics Education, 48(5), 593-596.

Kim, M. K., Kim, S. M., Khera, O., \& Getman, J. (2014). The experience of three flipped classrooms in an urban university: An exploration of design principles. The Internet and Higher Education, 22, 37-50. https://doi.org/10.1016/j.iheduc.2014.04.003

Kissi, P. S., Nat, M., \& Armah, R. B. (2018). The efects of learning family confict, perceived control over time and task-ft technology factors on urban-rural high school students' acceptance of videobased instruction in fipped learning approach. Educational Technology Research and Development, 66, 1547-1569. https://doi.org/10.1007/s11423-018-9623-9

Kong, S. C. (2015). An Experience of a three-year study on the development of critical thinking skills in flipped secondary classrooms with pedagogical and technological support. Computers and Education, 89, 16-31. https://doi.org/10.1016/j.compedu.2015.08.017

Krauss, R. M., \& Chiu, C. Y. (1998). Language and social behavior. In D. Gilbert, S. Fiske, \& G. Lindsey (Eds.), Handbook of Social Psychology 2 (pp. 41-88). McGraw-Hill.

Kuo, F. R., Hwang, G. J., \& Lee, C. C. (2012). A hybrid approach to promoting students' web-based problem-solving competence and learning attitude. Computers \& Education, 58(1), 351-364. https://doi.org/10.1016/j.compedu.2011.09.020

Lake, B. M., \& Murphy, G. L. (2021). Word meaning in minds and machines. Psychological Review. https://doi.org/10.1037/rev0000297

Leatherman, J. L., \& Cleveland, L. M. (2020). Student exam performance in flipped classroom sections is similar to that in active learning sections, and satisfaction with the flipped classroom hinges on attitudes toward learning from videos. Journal of Biological Education, 54(3), 328-344.

Lestari, I. W. (2021). Flipped classroom in Indonesian higher education: A mixed-method study on students' attitudes and experiences. Studies in English Language and Education, 8(1), 243-257.

Lincoln, Y. S., \& Guba, E. G. (2013). The constructivist credo. Left Coast Press.

Lo, C. K., \& Hew, K. F. (2017). A critical review of flipped classroom challenges in K-12 education: Possible solutions and recommendations for future research. Research and Practice in Technology Enhanced Learning, 12(1), 1-22.

Lohr, V. I., \& Bummer, L. H. (1992). Assessing and influencing attitudes toward water-conserving landscapes. Hort Technology, 2(2), 253-256. https://doi.org/10.21273/HORTTECH.2.2.253

Long, T., Logan, J., \& Waugh, M. (2016). Students' perceptions of the value of using videos as a preclass learning experience in the flipped classroom. TechTrends, 60(3), 245-252.

Love, B., Hodge, A., Grandgenett, N., \& Swift, A. W. (2014). Student learning and perceptions in a flipped linear algebra course. International Journal of Mathematical Education in Science and Technology, 45(3), 317-324.

Lucke, T., Dunn, P., \& Christie, M. (2016). Activating learning in engineering education using ICT and the concept of flipping the classroom. European Journal of Engineering Education, 42(1), 45-57. https://doi.org/10.1080/03043797.2016.1201460

Lundin, M., Bergviken Rensfeldt, A., Hillman, T., Lantz-Andersson, A., \& Peterson, L. (2018). Higher education dominance and siloed knowledge: Systematic review of flipped classroom research. International Journal of Educational Technology in Higher Education, 15(1), 1-30.

Mason, G. S., Shuman, T. R., \& Cook, K. E. (2013). Comparing the effectiveness of an inverted classroom to a traditional classroom in an upper-division engineering course. IEEE Transactions on Education, 56(4), 430-435. https://doi.org/10.1109/TE.2013.2249066

Mazur, A. D., Brown, B., \& Jacobsen, M. (2015). Learning designs using flipped classroom instruction. Canadian Journal of Learning and Technology, 41(2), 1-26.

McCarthy, J. (2016). Reflections on a flipped classroom in first year higher education. Issues in Educational Research, 26(2), 332-350. 
McKillup, S. (2012). Statistics explained: An introductory guide for life scientists (2nd ed.). Cambridge University Press.

McLaughlin, J. E., Roth, M. T., Glatt, D. M., Gharkholonarehe, N., Davidson, C. A., Griffin, L. M., Esserman, D. E., \& Mumper, R. J. (2014). The flipped classroom: A course redesign to foster learning and engagement in a health professions school. Academic Medicine, 89(2), 236-243. https://doi.org/10.1097/ACM.0000000000000086

Merriam, S. B. (2009). Qualitative research: A guide to design and implementation. John Wiley \& Sons.

Miller-Lewis, L. R., Lewis, T. W., Tieman, J., Rawlings, D., Parker, D., \& Sanderson, C. R. (2021). Words describing feelings about death: A comparison of sentiment for self and others and changes over time. PLoS ONE, 16(1), e0242848. https://doi.org/10.1371/journal.pone.0242848

Missildine, K., Fountain, R., Summers, L., \& Gosselin, K. (2013). Flipping the classroom to improve student performance and satisfaction. Journal of Nursing Education, 52(10), 597-599. https://doi. org/10.3928/01484834-20130919-03

Mkhymryahya, S., Ayasrah, M. N., \& Mansour al-etan, S. (2021). Barriers of using the flipped classroom strategy, from the standpoint of science teachers in Jordan. Multicultural Education, 7(9), 63-73.

Moffett, J. (2015). Twelve tips for "flipping" the classroom. Medical Teacher, 37(4), 331-336. https://doi. org/10.3109/0142159X.2014.943710

Naylor, S., \& Keogh, B. (1999). Constructivism in classroom: Theory into practice. Journal of Science Teacher Education, 10, 93-106. https://doi.org/10.1023/A:1009419914289

Flipped Learning Network [FLN], (2014). The four pillars of F-L-I-P. Retrieved from http://flippedlearning. org/cms/lib07/VA01923112/Centricity/Domain/46/FLIP_handout_FNL_Web.pdf

Neuman, L. W. (2014). Social research methods: Qualitative and quantitative approaches (7th ed.). Pearson Education Limited.

Nouri, J. (2016). The flipped classroom: For active, effective and increased learning-especially for low achievers. International Journal of Educational Technology in Higher Education, 13(1), 1-10.

Onah, J., Ebubechukwu, O., Eseni, N.O., \& Momohjimoh,F. (2021). Adopting flipped classroom model for effective library user education in Nigerian universities: Challenges and strategies. Library Philosophy and Practice, 1-15.

Osgood, C., Suci, G., \& Tannenbaum, P. (1957). The measurement of meaning. University of Illinois Press.

Palmer, K. (2015). Flipping a calculus class: One instructor's experience. PRIMUS: Problems, Resources, and Issues in Mathematics Undergraduate Studies, 25(9-10), 886-891. https://doi.org/10.1080/10511 970.2015 .1050618

Pedró, F. (2006). The new millennium learners: Challenging our views on ICT and learning. Inter-American Development Bank. Retrieved from https://publications.iadb.org/handle/11319/2432

Peled, Y., Blau, I., \& Grinberg, R. (2015). Does 1: 1 computing in a junior high-school change the pedagogical perspectives of teachers and their educational discourse? Interdisciplinary Journal of e-Skills and Life Long Learning, 11, 257-271.

Pierce, R., \& Fox, J. (2012). Vodcasts and active-learning exercises in a "flipped classroom" model of a renal pharmacotherapy Module. American Journal of Pharmaceutical Education, 76(10), 1-5. https://doi.org/10.5688/ajpe7610196

Preckel, F., Götz, T., \& Frenzel, A. (2010). Ability grouping of gifted students: Effects on academic selfconcept and boredom. British Journal of Educational Psychology, 80, 451-472.

Prensky, M. (2001). Digital natives, digital immigrants. NCB University Press, 9(5), 1-6.

Quyen, T. T., \& Loi, N. V. (2018). Flipped model for improving students' English speaking performance. Can Tho University Journal of Science, 54(2), 90-97. https://doi.org/10.22144/ctu.jen.2018.012

Ramírez, D., Hinojosa, C., \& Rodríguez, F. (2014, November). Advantages and disadvantages of flipped classroom: STEM students perceptions. In 7th International Conference of Education, Research and Innovation ICERI, Seville, Spain (pp. 17-19).

Robin, B. R. (2008). Digital storytelling: A powerful technology tool for the 21st century classroom. Theory into Practice, 47(3), 220-228. https://doi.org/10.1080/00405840802153916

Sağlam, D. (2016). The effect of flipped classroom model on the academic achievements and attitudes of students in English language teaching. Bülent Ecevit University.

Sağlam, D., \& Arslan, A. (2018). The effect of flipped classroom on the academic achievement and attitude of higher education students. World Journal of Education, 8(4), 170-176.

Salami, D. (2021). Attitude of science education students towards the use of mobile learning in Nigeria. ATBU Journal of Science, Technology and Education, 9(1), 38-43.

Siann, G., Macleod, H., Glissov, P., \& Durndell, A. (1990). The effect of computer use on gender differences in attitudes to computers. Computers \& Education, 14(2), 183-191. https://doi.org/10.1016/ 0360-1315(90)90058-F 
Singay, S. (2020). Flipped learning in the English as a second language classroom: Bhutanese students' perceptions and attitudes of flipped learning approach in learning grammar. Indonesian Journal of Applied Linguistics, 9(3), 666-674.

Snyder, C., Paska, L. M., \& Besozzi, D. (2014). Cast from the past: Using screencasting in the social studies classroom. The Social Studies, 105(6), 310-314.

Storey, L. (2007). Doing Interpretative Phenomenological Analysis. In E. Lyons \& A. Coyle (Eds.), Analyzing Qualitative Data In Psychology (pp. 51-64). SAGE Publications.

Strayer, J. F. (2011). The flipped classroom: Turning traditional education on its head. Retrieved from http:// www.knewton.com/flipped-classroom/

Strelan, P., Osborn, A., \& Palmer, E. (2020). The flipped classroom: A meta-analysis of effects on student performance across disciplines and education levels. Educational Research Review, 30, 100314. https://doi.org/10.1016/j.edurev.2020.100314

Su, C. Y., \& Chen, C. H. (2018). Investigating the effects of flipped learning, student question generation, and instant response technologies on students' learning motivation, attitudes, and engagement: A structural equation modeling. EURASIA Journal of Mathematics, Science and Technology Education, 14(6), 2453-2466.

Subotnik, R. F., Olszewski-Kubilius, P., \& Worrell, F. C. (2011). Rethinking giftedness and gifted education: A proposed direction forward based on psychological science. Psychological Science in the Public Interest, 12, 3-54.

Sue, J., \& Huo, X. (2017). A study on the motivational strategies in college English flipped classroom. English Language Teaching, 10(5), 62-67.

Talbert, R. (2014). Inverting the linear algebra classroom. Primus, 24(5), 361-374. https://doi.org/10.1080/ 10511970.2014 .883457

Tarigan, F. N. (2021). Fostering university students' attitude toward utilization of E-learning. Journal of Community Research and Service, 5(2), 52-57.

Thai, N. T. T., De Wever, B., \& Valcke, M. (2017). The impact of a flipped classroom design on learning performance in higher education: Looking for the best "blend" of lectures and guiding questions with feedback. Computers \& Education, 107(1), 113-126.

Thomson, D. L. (2010). Beyond the classroom walls: Teachers' and students' perspectives on how online learning can meet the needs of gifted students. Journal of Advanced Academics, 21, 662-712.

Touchton, M. (2015). Flipping the classroom and student performance in advanced statistics: Evidence from a quasi-experiment. Journal of Political Science Education, 11(1), 28-44. https://doi.org/10.1080/ 15512169.2014.985105

Tutal, Ö., \& Yazar, T. (2021). Flipped classroom improves academic achievement, learning retention and attitude towards course: a meta-analysis. Asia Pacific Education Review, 22(4), 655-673.

Wanner, T., \& Palmer, E. (2015). Personalizing learning: Exploring student and teacher perceptions about flexible learning and assessment in a flipped university course. Computers and Education, 88, 354-369.

Webb, M., \& Doman, E. (2020). Impacts of flipped classrooms on learner attitudes towards technologyenhanced language learning. Computer Assisted Language Learning, 33(3), 240-274.

Wehrwein, E. A., Lujan, H. L., \& DiCarlo, S. E. (2007). Gender differences in learning style preferences among undergraduate physiology students. Advances in Physiology Education, 31(2), 153-157.

Wei, X., Cheng, I. L., Chen, N. S., Yang, X., Liu, Y., Dong, Y., et al. (2020). Effect of the flipped classroom on the mathematics performance of middle school students. Educational Technology Research and Development, 68, 1461-1484. https://doi.org/10.1007/s11423-020-09752-X

Yestrebsky, C. L. (2015). Flipping the classroom in a large chemistry class-research university environment. Procedia-Social and Behavioral Sciences, 191, 1113-1118. https://doi.org/10.1016/j.sbspro.2015.04. 370

Publisher's Note Springer Nature remains neutral with regard to jurisdictional claims in published maps and institutional affiliations. 